\title{
Youth crime and education expansion
}

Citation for published version (APA):

Machin, S., Marie, O., \& Vujic, S. (2012). Youth crime and education expansion. METEOR, Maastricht University School of Business and Economics. METEOR Research Memorandum No. 036

https://doi.org/10.26481/umamet.2012036

Document status and date:

Published: 01/01/2012

DOI:

10.26481/umamet.2012036

Document Version:

Publisher's PDF, also known as Version of record

\section{Please check the document version of this publication:}

- A submitted manuscript is the version of the article upon submission and before peer-review. There can be important differences between the submitted version and the official published version of record.

People interested in the research are advised to contact the author for the final version of the publication, or visit the DOI to the publisher's website.

- The final author version and the galley proof are versions of the publication after peer review.

- The final published version features the final layout of the paper including the volume, issue and page numbers.

Link to publication

\footnotetext{
General rights rights.

- You may freely distribute the URL identifying the publication in the public portal. please follow below link for the End User Agreement:

www.umlib.nl/taverne-license

Take down policy

If you believe that this document breaches copyright please contact us at:

repository@maastrichtuniversity.nl

providing details and we will investigate your claim.
}

Copyright and moral rights for the publications made accessible in the public portal are retained by the authors and/or other copyright owners and it is a condition of accessing publications that users recognise and abide by the legal requirements associated with these

- Users may download and print one copy of any publication from the public portal for the purpose of private study or research.

- You may not further distribute the material or use it for any profit-making activity or commercial gain

If the publication is distributed under the terms of Article $25 \mathrm{fa}$ of the Dutch Copyright Act, indicated by the "Taverne" license above, 


\section{Maastricht University}

Stephen Machin, Olivier Marie, Sunčica Vujić

Youth Crime and Education Expansion

RM/12/036

\section{METEOR}

Maastricht University School of Business and Economics

Maastricht Research School of Economics

of Technology and Organization

P.O. Box 616

NL - 6200 MD Maastricht

The Netherlands 


\title{
Youth Crime and Education Expansion
}

\author{
Stephen Machin*, Olivier Marie ${ }^{* *}$ and Sunčica Vujić****
}

June 2012

\begin{abstract}
* Department of Economics, University College London and Centre for Economic Performance, London School of Economics

** Research Centre for Education and the Labour Market (ROA), Maastricht University and Centre for Economic Performance, London School of Economics

*** Department of Economics, University of Bath
\end{abstract}

\begin{abstract}
$\underline{\text { Abstract }}$
We present new evidence on the causal impact of education on crime, by considering a large expansion of the UK post-compulsory education system that occurred in the late 1980s and early 1990s. The education expansion raised education levels across the whole education distribution and, in particular for our analysis, at the bottom end enabling us to develop an instrumental variable strategy to study the crime-education relationship. At the same time as the education expansion, youth crime fell, revealing a significant cross-cohort relationship between crime and education. The causal crime reducing effect of education is estimated to be negative and significant, and considerably bigger in (absolute) magnitude than ordinary least squares estimates. The education boost also significantly impacted other productivity related economic variables (qualification attainment and wages), demonstrating that the incapacitation effect of additional time spent in school is not the sole driver of the results.
\end{abstract}

JEL Keywords: Youth crime; Education expansion.

JEL Classifications: I2; K42.

Corresponding author: Sunčica Vujić, Department of Economics, University of Bath, Claverton Down, Bath, BA2 7AY, United Kingdom, Email: s.vujic@,bath.ac.uk

Acknowledgements

We would like to thank the Editor and two anonymous referees for a number of useful comments and suggestions. Marie would like to thank the Executive Research Agency of the European Union for funding under the Marie Curie IEF grant number 252572. 


\section{$\underline{1 . \text { Introduction }}$}

A small, but growing, economic literature has presented empirical evidence showing a negative causal impact of education on crime. For the United States, Lochner and Moretti (2004) use variations in compulsory school leaving age laws across states to identify the impact of education on crime, and Machin, Marie and Vujić (2011) exploit the raising of the school leaving age across cohorts in England and Wales to do the same. Both studies uncover a robust and sizable crime reducing effect of education. ${ }^{1}$

In this paper, we also consider the causal impact of education on crime, but adopt a different route to identification. We present new evidence on the causal relationship, by studying what happened to crime in a period when the UK postcompulsory education system was very rapidly expanded. This large expansion occurred in the late 1980s and early 1990s and significantly raised education levels across the whole education distribution, thereby considerably reducing the number of individuals with low education levels in birth cohorts exposed to the expansion. Our approach is to think of these cohorts as a 'treated' set of individuals whose education was raised and we can compare their education and crime outcomes with a 'control' set of cohorts who did not benefit from the expansion.

The education expansion we consider has been studied in other areas. Blanden and Machin's (2004) study focuses on the expansion as a key driver of falling intergenerational mobility. Devereux and Fan (2011) have also looked at wage effects associated with the education expansion, showing that on average it caused men and women to gain respectively a year or slightly more than a year of education and that this significantly raised wages. By considering the education expansion as an exogenous increase in educational attainment, they present causal estimates of the

\footnotetext{
${ }^{1}$ See also Lochner's (2011) review of empirical work on the non-wage benefits of education where part of his focus is to review evidence on the crime-education relationship.
} 
wage return to an extra year of schooling of about six percent for both men and women.

To preview our results, we also report significant improvements in education levels for cohorts affected by the education expansion. Given our focus on crime, it is important that education improvements occurred at the bottom end of the education distribution, as this is where its impact is most likely to affect offending behaviour. We spend some time in our empirical analysis showing this to be the case. We then consider what happened to crime for the treated cohorts relative to the control cohorts and we show evidence that youth crime fell significantly as educational attainment rose.

We present causal estimates in an instrumental variable setting, where a 1 percent increase in the proportion of male students reduces male youth crime by around 1.9 percent and a 1 percent increase in the proportion of men staying on at school after the compulsory school leaving age reduces male youth crime by around 1.7 percent. Whilst going in the same direction, results for women are smaller with youth crime reductions of somewhere between 1.1 and 1.3 percent. For young men, we also find that education causally reduces both property and violent crimes.

Finally, we discuss mechanisms underpinning the crime-education relation and present evidence that the education boost from expansion also significantly impacted other productivity related economic variables (qualification attainment and wages). We interpret this as showing that keeping people in the education system (incapacitation) is not the sole driver of the results, because the education boost is also associated with better, productivity-raising, economic outcomes.

The rest of the paper is organised as follows. Section 2 offers a brief discussion of the relevant literature, with an emphasis on the mechanisms behind the education- 
crime relationship and their implications for our empirical analysis. Section 3 describes the nature of the education expansion and the data sources we use. Section 4 first shows the impact of the education expansion on the education distribution, before moving on to report results from a causal analysis of the crime and education relationship. In Section 5, we consider potential mechanisms underpinning the causal crime-education relationship by also looking at other economic effects of the education expansion. Section 6 concludes.

\section{Education and Crime: Mechanisms and Implications}

\section{Mechanisms}

There are number of theoretical reasons why education can impact on crime. Existing literature highlights (at least) three main channels through which schooling might affect criminal participation: income effects, patience or risk aversion, and time availability. We consider each of these three mechanisms in turn:

(i) Income effects operate through education reducing crime by increasing the returns to legitimate work and/or by raising the opportunity costs of illegal behaviour (Lochner, 2004; Lochner and Moretti, 2004; Hjalmarsson, 2008). Empirical work connecting crime to low wages broadly supports this notion (Gould et al., 2002; Grogger, 1998; Machin and Meghir, 2004; Mocan and Unel, 2011). However, there is some counter-evidence that education can also increase the earnings from crime for some crime types as certain skills acquired in school can be used when engaging in criminal activities. $^{2}$

\footnotetext{
${ }^{2}$ Levitt and Lochner (2001) report that males with higher scores on mechanical information tests had increased offence rates and Lochner (2004) reports some cross-cohort evidence that increases in average education are associated with higher white-collar arrest rates (although this finding is not statistically significant at conventional levels).
} 
(ii) Patience and risk aversion are also mechanisms through which education may impact on crime. Individuals with a lot of patience tend to have low discount rates and therefore value future earnings more highly as compared to individuals with higher discount rates. Indeed, Oreopoulos (2007) presents evidence that young people who drop out of school tend to be myopic and are more focussed on immediate costs of schooling, rather than on future gains from an additional year of schooling. Thus, he argues that dropouts are more predisposed to risky behaviour. Similarly, education can increase patience, thereby reducing the discount rate of future earnings, and in turn lowering the propensity to commit crimes. Education may also increase risk aversion and this can increase the weight individuals perceive to be attached to a possible punishment, which consequently reduces crime.

(iii) Time spent in education can also have an impact. A 'self-incapacitation' effect was documented by Tauchen et al. (1994) who found time spent at school (and work) during a year to be negatively correlated with the probability of arrest that year. Hjalmarsson (2008) looked at the opposite relationship, studying the impact of being arrested and incarcerated before finishing school on the probability of graduating high school. Her results suggest that the number of times being caught committing crime and the amount of time spent in prison both greatly increase the likelihood of becoming a high school dropout.

These are likely to be endogenous decisions, hence Jacob and Lefgren (2003) instrument days off school with exogenous teacher training days. Luallen (2006) uses unexpected school closings driven by teacher strikes as an instrument for student absence from school. Both of these papers report there to be important incapacitation effects of additional time spent in education on criminal participation. However, they also report that violent offences increase while school is in session, a finding that is 
attributed to a concentration effect. ${ }^{3}$ Anderson (2009) also reports evidence for the United States, based on minimum high school dropout ages that vary across states, that keeping youth in school decreases arrest rates.

\section{Implications}

After obtaining estimates of the impact of education expansion on crime, an issue we will face is to interpret them in view of these potential mechanisms that underpin the crime-education relation. This is important here as the outcome variable we will focus on measures convictions of young individuals aged 16 to 21 and the education expansion we study substantially increased the educational participation of this age group. ${ }^{4}$ Our estimates will therefore have a component that could be attributed to the self-incapacitation effect due to certain cohorts of youths spending more time at school. It is hard to completely rule out an incapacitation effect, but we will present evidence that try to establish that this may not be the sole explanationof any crime reductions that result from education expansion.

A first attempt to consider this comes about because of differences between our approach and that of the other existing causal studies. Lochner and Moretti (2004) for the US and Machin, Marie, and Vujić (2011) - MMV (2011) henceforth - for England and Wales exploit changes in compulsory school leaving age laws to identify the causal impact of an extra year of schooling on criminal participation. The cohort level approaches of these papers is methodologically akin to the one we will adopt, but both studies are able to mostly rule out any direct self-incapacitation effect of education on crime. They do so by excluding the age group affected by the extra school year

\footnotetext{
${ }^{3}$ The term concentration effect refers to the presence of a large number of youths in an educational establishment, which may result in an increased probability of violent encounters.

${ }^{4}$ Whilst we want to study youth crime, the chosen age group is in part necessitated by data limitations. More specifically, the Offenders Index Database (described below) is only available until 2002 and we therefore chose to limit our analysis to the age group 16 to 21 in order to have a relatively balanced panel and enough cohorts around the ones treated by the policy. See the Data Appendix (available in the online version of this article) for details on the structure of the OID.
} 
brought about by the policies studied from the arrest or conviction data used. The findings from these papers are similar and point to (approximately) a 1 percent drop in male property crime for every 1 percent of a male cohort obtaining some educational qualification as a result of the reforms. Both studies find no significant effect on female offending rates. The impact on male violent crime is less conclusive and while Lochner and Moretti (2004) obtain relatively large (albeit imprecise) estimates, MMV (2011) do not find a significant effect of education on this outcome.

Thus, a first simple way to attempt and disentangle which mechanism is driving our results will be to benchmark our findings to those of MMV (2011). As their results are 'net' of self-incapacitation effects, we might expect to see a stronger effect on male property convictions in our context of studying youth crime and tentatively attribute some of the difference directly to the extra time spent in school. Perhaps more relevant will be the interpretation of a potential education effect on male violent offences. Economic theory does not give much support to the existence of an income effect mechanism for this type of criminal behaviour and this is why MMV (2011) argued that it was not surprising they found no impact of education on violent offending. There is, however, no reason to assume that violent offending is not affected via the self-incapacitation channel for youths. ${ }^{5}$ We could therefore also tentatively interpret a connection between young male violent convictions and education as stemming from this mechanism.

A second possible route to investigate the underlying mechanisms of an education impact on crime is to consider whether the education boost from expansion impacted other productivity related outcomes. If we uncover evidence of this, then we

\footnotetext{
${ }^{5}$ For example, Sabates (2010) and Sabates and Feinstein (2008) found evidence of reduced convictions for both 'antisocial behaviour' and burglary when studying a localised post-compulsory schooling incentivization scheme in a British context. These papers do not however investigate which potential mechanisms are driving these results.
} 
can plausibly rule out that the incapacitation effect is the sole explanation of a crime reducing effect of education. For example, if part of the changes in youth crime can be attributed to an income impact of education expansion, this would be reflected in differences in productivity related measures such as higher qualification attainment, wages, and unemployment across treated and non-treated cohorts.

We will therefore also estimate the causal impact of education increases induced by the expansion on these economic outcomes. This has similarities to the analysis of wage returns to education expansion carried out by Devereux and Fan (2011) who report significant wage returns associated with education expansion, though they focus on older individuals (aged 25 to 50) than we will do, and use a smaller number of years of the Labour Force Survey data (see the discussion below and in the Data Appendix available in the online version of this article).

\section{$\underline{\text { 3. Expansion of the UK Post-Compulsory Education System }}$}

The post-compulsory education system in the UK has hugely expanded since the 1960s. Figure 1 shows two post-compulsory education participation series between 1960 and 2002: (a) the rate of staying on beyond the compulsory school leaving age, and (b) the higher education age participation index (API). ${ }^{6}$ The Figure shows increases in both series from 1960 onwards.

A closer look at Figure 1 reveals that the staying on series appears to have been on a steadily increasing path (although is subject to some cyclical variations) from the start of the series through to the mid-1980s. However, from the late 1980s/early 1990s there is a rapidly occurring step-change as staying on rates rise much faster, especially between 1988 and 1992, before plateauing out in the mid 1990s.

\footnotetext{
${ }^{6}$ The API is the proportion of individuals aged under 21 who enter higher education each year.
} 
The increase in university participation is also very rapid, as shown by the API. There was a sharp expansion in the 1960s, when the age participation index doubled from 6 to 14 percent. It then rose marginally from this level through until the late 1980s, after which it grew even more rapidly than the 1960s change. By 2001 it had reached 35 percent, rising up from under 20 percent at the start of the 1990s.

Figure 1 makes it clear that a very rapid education expansion took place in the late 1980s/early 1990s in the UK, and that it occurred at lower and higher parts of the education distribution. The fact that the staying on rate rose, and hence there were fewer people leaving school at the compulsory school leaving age of 16 , is important and we will probe the nature and scale of this change in more detail with available micro-data.

It is also worth reflecting on why the expansion of post-compulsory schooling took place. Blanden and Machin (2004) emphasise two main factors. For the expansion of the post-compulsory sector through increased staying on rates, they highlight the change in the school leaving examination system that took place in 1988 , with the introduction of the General Certificate of Secondary Education (GCSE) and the consequent improvement in examination results. $^{7}$ For higher education (HE) participation, they discuss increased university enrolment in the light of changes in admissions and in financing, together with the perception of increased wage returns to HE facilitated by very fast rises in the wage returns to a degree that occurred throughout the 1980s, as a key part of a general rise in wage inequality (see, inter alia, Machin and Vignoles, 2005).

\footnotetext{
${ }^{7}$ The GCSE examinations are taken at the end of the last year of compulsory schooling (at age 16). Therefore the first affected cohort by this change was the cohort of students born in 1972. This will be important to keep in mind when defining treated cohorts for our identification below.
} 
We must finally note that there is no evidence, to our knowledge, that the political decision to expand educational attainment was motivated as a response to particular trends in youth crime rates. It was also not specifically combined with other crime fighting policies aimed at certain age groups or cohorts, thus making it a good potential instrument to study the causal impact of education on offending.

\section{Data Description}

To study the impact of this education expansion on educational attainment and crime there are a number of pertinent data issues that need to be discussed. The key issue we face is that no single individual-level data source exists to study crime and education effects working through this policy. We thus need some means of matching crime and education data from different sources.

To do so we match at cohort level convictions data for England and Wales from the Offenders Index Database (OID) with education data from the Labour Force Survey (LFS). The OID contains criminal history data for offenders convicted of standard list offences from 1963 and up to $2002 .^{8}$ The data (which are described in more detail in the Data Appendix available in the online version of this article) are derived from the court appearances system and are updated quarterly. The Index was created purely for research and statistical analysis. Its main purpose is to provide full criminal history data on a randomly selected sample of offenders. We have access to OID data on anonymous samples for offenders sentenced during four weeks each year. We also have the entire pre- and post-court appearance history of these individuals. However, there is no information on a defendant's education level in the OID and so the data needs to be aggregated and matched to education data from other sources. A

\footnotetext{
${ }^{8}$ Standard list offences are all indictable or triable offences, plus a few of the more serious summary offences.
} 
big advantage (certainly relative to recorded offences data) is that some demographic characteristics are available in the OID, notably age and gender.

We therefore calculated offending rates (per 10,000 population) using Office for National Statistics (ONS) population data by birth cohort and year, separately for men and women. In doing so, criminal offences were also broadly categorised as property crimes (burglary and theft and handling of stolen goods) and violent crimes (violence against the person and robbery). These offending rates can be matched to education data from other micro-data sources where education measures can be collapsed into birth cohort by year and gender cells.

We constructed education measures for the same birth cohorts by year and gender cells from the LFS. The Data Appendix (available in the online version of this article) describes more fully how we matched the OID and the LFS data for the main analysis in this paper. Our focus is on youth crime and so our sample consists of birth cohorts aged 16 to 21 born between 1962 and 1982 from OID and LFS data across the 1978 to 2002 time period. $^{9}$ This ensures the panel of cohorts is relatively well balanced, especially around the years of the policy intervention (see the Data Appendix available in the online version of this article for more details).

We focus upon two education measures:

i) the proportion of 16 to 21 year-olds in full time education;

ii) the proportion of 16 to 21 year-olds who stayed on after the compulsory school leaving age (of 16).

We look at the relationship between youth crime and these education measures, using the education expansion as an exogenous shock that we can exploit in order to

\footnotetext{
${ }^{9}$ In the early years of the LFS, the survey was biannual (in 1975, 1977, 1979, 1981 and 1983), after which it became annual. Therefore, we imputed values for missing years by interpolation (see the Data Appendix available in the online version of this article).
} 
identify the causal impact of education on youth crime. For this to be a legitimate exercise, we need to show that the expansion which, as we argued above, was driven by the reform of the school leaving exams (the move to the GCSE system) and a subsequent rise in higher education participation, raised the education measures that we look at.

Figure 2 shows the cross-cohort evolution of the two education measures defined above. The upper Figure shows the proportion of the cohort still in full-time education and the lower Figure shows the proportion staying on after the compulsory school leaving age (of 16). In each of these, the dotted line is for women and the solid line for men. A very clear pattern is present for both measures. For the 1962 to 1971 birth cohorts the education measures slowly rise (more so for women than men). The next four birth cohorts (1972 to 1975) show very rapid increases. The 1972 birth cohort was the first to take the GCSE exams in $1988 .{ }^{10}$ Thereafter, for cohorts born in 1976 and later, the education measures plateau out at a higher level.

Thus, it seems that the education expansion occurred very strongly for the 1972 to 1975 birth cohorts. Indeed, Blanden and Machin (2004) and Devereux and Fan (2011) show that this increase also extended to higher education participation once these cohorts became old enough (see also the earlier discussion of Figure 1).

Our interest is in whether the expansion impacted youth crime. This is considered in Figure 3, which shows OID conviction rates by gender (measured as convictions per 10,000 men or women) for the 1962 to 1982 birth cohorts. The solid

\footnotetext{
${ }^{10}$ The increases in education illustrated in Figure 2 may have already begun to slightly accelerate for older male cohorts born in 1970 and 1971. Indeed, Devereux and Fan (2011) include these two birth cohorts in their IV strategy. However, closer inspection of Figure 2 does reveal that, as expected, most of the policy impact seems to be concentrated on those turning 16 in 1988 or after when the new examination system was officially implemented. We therefore consider cohorts born between 1972 and 1975 as the treated ones throughout our analysis. However, if we used the Devereux-Fan definition and included 1970 and 1971 cohorts into the IV strategy, this produced very similar IV estimates that were never statistically different than for our preferred specifications presented here. These are available from the authors upon request.
} 
line shows that male convictions rose for the 1962 to 1971 cohorts, but fell very sharply for the education expansion cohorts, and fell more slowly after that. The faster fall for the 1972 to 1975 cohorts is suggestive of a crime fall happening because of the expansion. For women, as shown by the dotted line, the conviction rates are noisier (owing to there being far fewer female convictions), but a relatively similar pattern emerges.

For men, we have big enough sample sizes to also break down convictions in those for property and violent crimes. This is done in Figure 4. The sharp reduction in conviction rates is seen for both crime types. Their evolutions are slightly different in that violent convictions seem to rise again after the education expansion period but, based on the descriptive analysis, the notion that education increased rapidly and that convictions fell at the same time seems to be the case. In the next Section of the paper, we model this more formally, and use the variation in education induced by the expansion to present estimates of the causal impact of education on youth crime.

\section{Statistical Estimates of the Crime-Education Relationship}

\section{Reduced and Structural Forms}

We begin our statistical analysis by considering education and crime reduced form models. Formally, these can be represented as follows for each age, subscript a (16 to 21), and year, subscript t (1982 to 2002), cells:

$$
\begin{aligned}
& \mathrm{ED}_{\mathrm{at}}=\alpha_{0}+\alpha_{1} \mathrm{EE}_{\mathrm{at}}+\sum_{\mathrm{j}=1}^{\mathrm{J}}\left(\varphi_{1 \mathrm{j}} \mathrm{COH}_{\mathrm{at}}^{\mathrm{j}}+\varphi_{2 \mathrm{j}} \mathrm{AGE}_{\mathrm{at}}^{\mathrm{j}}\right)+\varphi_{3} \mathrm{Z}_{\mathrm{at}}+v_{\mathrm{at}} \\
& \mathrm{C}_{\mathrm{at}}=\beta_{0}+\beta_{1} \mathrm{EE}_{\mathrm{at}}+\sum_{\mathrm{j}=1}^{\mathrm{J}}\left(\lambda_{1 \mathrm{j}} \mathrm{COH}_{\mathrm{at}}^{\mathrm{j}}+\lambda_{2 \mathrm{j}} \mathrm{AGE}_{\mathrm{at}}^{\mathrm{j}}\right)+\lambda_{3} \mathrm{Z}_{\mathrm{at}}+\omega_{\mathrm{at}}
\end{aligned}
$$

where $\mathrm{ED}$ is education, $\mathrm{C}$ is crime, EE denotes the education expansion cohorts, where each reduced form equation contains a $\mathrm{J}^{\text {th }}$ order polynomial in birth cohort $(\mathrm{COH})$ and 
age (AGE) - in most models below we include a quadratic $(\mathrm{J}=2)$ effect in cohort and a cubic $(\mathrm{J}=3)$ effect in age. $\mathrm{Z}$ is a set of time varying demographic controls constructed from the LFS (which are the age-year proportions of: non-white, living in London, and from Wales), and $v$ and $\omega$ are equation error terms.

The reduced form parameters in (1) are related to the parameters of the following crime structural form that models the causal crime-education relationship:

$$
\mathrm{C}_{\mathrm{at}}=\theta_{0}+\theta_{1} \mathrm{ED}_{\mathrm{at}}+\sum_{\mathrm{j}=1}^{\mathrm{J}}\left(\gamma_{1 \mathrm{j}} \mathrm{COH}_{\mathrm{at}}^{\mathrm{j}}+\gamma_{2 \mathrm{j}} \mathrm{AGE}_{\mathrm{at}}^{\mathrm{j}}\right)+\gamma_{3} \mathrm{Z}_{\mathrm{at}}+\varepsilon_{\mathrm{at}}
$$

where the instrumental variable/two stage least squares (IV/2SLS) estimate of the coefficient on the education variable in (2) is the ratio of the reduced form coefficients in (1), $\theta_{1}=\beta_{1} / \alpha_{1}$.

\section{Reduced Form Estimates}

Table 1 shows the reduced form estimates (equation (1)) for the two education variables and for the total conviction rate for male and female cohorts. The education expansion cohorts (EE in (1)) are modelled through the inclusion of four cohort dummies, for birth cohorts 1972 through 1975. Each specification also includes a postEE cohort dummy to pick up the plateauing out, shown in the earlier education Figures. The cohort effects are therefore estimated relative to cohorts born in 1971 or before (the pre-GCSE examination period).

There are several interesting features of the results. Consider those for men first. The estimated coefficients on the cohort dummies in the education equations show significant step changes upwards, going from 0.031 to 0.137 from the 1972 to 1975 cohort, for the proportion of students in the cohort, and then plateauing out at 0.145. The same kind of pattern, going from 0.028 to 0.163 and plateauing out at 0.184 is seen for the staying on at age 16 variable. Moreover, as the F-tests in the Table 
shows, these cohort dummies of the education impact of the reform are strongly significant with large $F$-statistics (and associated $p$-values of 0.00 ). This supports use of the cohort dummy variables as instruments in the causal estimations that we will discuss in due course.

The conviction rate reduced form also shows a step change pattern, but this time the estimated coefficients on the cohort dummies are negative, going from -0.050 to -0.239 , and again showing the plateauing out feature with an estimated coefficient of -0.248 on the post-EE cohort dummy variable. Similarly, the F-statistic testing for the exclusion of the 1972 through 1975 cohort dummies being equal to zero is strongly significant, with an F-statistic of 10.59 (and associated p-value of 0.00 ). We can therefore conclude that for men, education significantly rose amongst the EE cohorts, whilst at the same time their conviction rate fell.

For women, the pattern is qualitatively similar. There is evidence of strong educational improvements, again with significant $F$-statistic testing the joint significance of the EE cohort dummies. However, the crime reduced form is somewhat weaker than the male one and the hypothesis of joint insignificance of the estimated treated cohort effects can be rejected only at the 5 percent level. As discussed earlier, this probably reflects the more infrequent occurrences of female convictions and thus the noisier data.

\section{Structural Form Estimates}

Table 2 shows ordinary least squares (OLS) estimates of the crime-education association and the causal 2SLS structural form estimates (of equation (2)) for male and female cohorts. The OLS estimates reveal a negative association between the conviction rate and both education measures, for both men and women, though the estimated coefficients are not significant for women. The causal 2SLS estimates (using 
the EE cohort dummies as instruments for the education variables) are greater in (absolute) magnitude in all cases, and statistically significant (albeit only at the 5 percent level for women). The 2SLS results show that a 1 percent increase in the proportion of male students reduces male youth crime by around 1.9 percent and a 1 percent increase in the proportion of men staying on at school after the compulsory school leaving age reduces male youth crime by around 1.7 percent. Whilst going in the same direction, results for women are smaller with youth crime reductions of somewhere between 1.1 and 1.3 percent resulting from a 1 percent increases in the proportion of female students and the proportion of females staying on respectively.

Thus, our first conclusion is that we are able to identify a quantitatively important and strongly significant causal youth crime reducing effect of education, especially for young men, working through the education expansion induced by the reform of the examination system.

Property and Violent Crimes

In the existing literature, when crimes are broken down into property and violent crimes, there is some disagreement about whether one can identify a causal effect for both (for example, Lochner and Moretti's, 2004, US work reports evidence for both, whereas the England and Wales analysis of MMV, 2011, only reports a significant effect for property crimes). In Table 3 we therefore consider property crime convictions and violent crime convictions separately. These are considered for young men only, because of the low frequency of female violent crime convictions. Consider first the crime reduced forms in the left panel of Table $3 .{ }^{11}$ For both property and violent crime convictions we see the same kind of pattern as before, with

\footnotetext{
${ }^{11}$ The reduced forms for education remain the same as the ones already reported for males in Table 2.
} 
there being a step change, followed by a plateauing out. The F-statistic of joint significance is stronger for property than violent crimes.

Given these estimates, it is not surprising that we identify a significant causal effect of education on property and violent crime convictions amongst young men. The 2SLS estimates in the right panel of Table 3 are again large in absolute magnitude, that is, about 4 to 5 times larger than the corresponding OLS estimates. Thus our second main conclusion is that, for young men, our estimates uncover a causal crime reducing effect of education for both property and violent crime convictions.

\section{Effects on Other Economic Outcomes}

In Section 2 of the paper, we argued that looking at the impact of education on other productivity related outcomes gives potential to rule out the notion that the only mechanism at work in explaining the causal impact of education on crime is an incapacitation effect. The stronger impacts on male property and violent crimes than found by MMV (2011) do suggest that increased time spent at school had a direct impact on criminal behaviour. However, in order to argue that it was or not the only channel at play, we need to investigate if education expansion had an impact on other outcomes (principally working through what we labelled the income effect earlier in the paper). To do so, we consider the causal impact of education on productivity related outcomes later in life (when aged 25 to 30) for our treated individuals, once the vast majority have completed their education. The productivity related outcomes we consider are qualification attainment and wages. ${ }^{12}$

\footnotetext{
12 In an earlier version of this paper, we also considered unemployment as an outcome. The reduced form for unemployment was not very strong and whilst the estimated effects went in the direction of unemployment reductions from education expansion, the IV results were very imprecise. These results are available from the authors on request.
} 
In this Section, we are not forced to carry out a cohort level analysis since we observe both the education variables and the productivity related outcomes at individual level in the Labour Force Survey. Thus we can carry out individual analysis of the relationship between these outcomes and the education variables affected by the education expansion reform. ${ }^{13}$ We consider two education variables we can measure at the individual level: a) whether the individual stayed on at school after the compulsory school leaving age of 16; and b) age left full-time education.

The upper panel of Table 4 shows reduced form estimates for the two education variables and for qualification attainment and for wages (both weekly and hourly). As with the earlier, cohort-based analysis, the education variables are strongly related to the 1972 to 1975 cohort dummies, with the same step-up pattern across cohorts, and then a plateauing out, being observed. Again the $F$-tests of joint significance of the cohort dummies are sizable.

There are also strong, similarly structured, reduced forms for qualification attainment (here measured as whether an individual only achieves a low qualification see the Data Appendix, available in the online version of this article, for precise details) and wages (both weekly and hourly). The probability of achieving a low qualification falls across the cohorts and then plateaus out, whilst wages significantly improve.

The lower panel of Table 4 shows OLS and 2SLS estimates of the relationship between the productivity related outcomes of interest and the education variables where (in the case of 2SLS) the education expansion cohort dummies are used as instruments. We identify a causal impact of increased education due to the expansion

\footnotetext{
${ }^{13}$ In terms of the actual empirical specification, this means that we are no longer restricted to age-year cells (subscript at in the models above) and can look at the individual outcomes in a particular year (with the generic subscript it). Moreover we can now use dummies for the demographic controls (i.e., being non-white, living in London, or from Wales) rather than age-year proportions used before.
} 
that significantly reduces the probability of leaving school with low qualifications and boosts both weekly and hourly earnings.

It is interesting that the 2SLS estimates for qualification attainment and wages, as with the earlier crime results, are 2 to 3 times larger in (absolute) magnitude than the least squares results. We read these as showing a productivity enhancing effect of the extra time spent in education because of the education expansion. Thus, we conclude that this productivity increasing aspect of the education expansion means that we can rule out the notion that the only mechanism underpinning the significant crime reducing impact of education is incapacitation.

\section{$\underline{\text { 6. Conclusions }}$}

In this paper, we revisit the small, but growing, economic literature on the causal crime reducing effect of education. We adopt a different route to identification compared to the papers using raisings of the compulsory school leaving age. Instead, we study an expansion of the post-compulsory education system that occurred in the UK for cohorts of young people born between 1972 and 1975 who faced a change in the school leaving examination system in 1988 when they reached the compulsory school leaving age. This reform significantly expanded the number of individuals who participated in post-compulsory education as full-time students who stayed on after the compulsory school leaving age.

We use this variation in post-compulsory education participation to identify the causal impact of education of crime. For young men, we report a strong crime reducing effect of education, which is bigger in (absolute) magnitude than that implied by least squares regressions. A 1 percent increase in the proportion of male students reduces male crime by around 1.9 percent and a 1 percent increase in the proportion of men 
staying on at school after the compulsory school leaving age reduces male crime by around 1.7 percent. We also find crime reducing effects for young women, though these are smaller with crime reductions of somewhere between 1.1 and 1.3 percent. For young men, we also find that education causally reduces both property and violent crimes.

Finally, we also find that the education boost from expansion significantly affected other productivity related economic variables (qualification attainment and wages), which we interpret as saying that keeping people in the education system (incapacitation) is not the sole driver of the results. Rather, over and above the incapacitation effects that exist, there is also a productivity enhancing aspect of the increased time spent in post-compulsory education that has a direct crime reducing impact. 


\section{$\underline{\text { References }}$}

Anderson, D. M. (2009), "In School and Out of Trouble? The Minimum Dropout Age and Juvenile Crime," University of Washington, mimeo.

Blanden, J. and S. Machin (2004), "Educational Inequality and the Expansion of UK Higher Education," Scottish Journal of Political Economy 51, 230-49.

Devereux, P. and W. Fan (2011), "Earnings Returns to the British Education Expansion," Economics of Education Review 30, 1153-1166.

Devereux, P. and R. Hart (2010), "Forced to be Rich? Returns to Compulsory Schooling in Britain,” Economic Journal 120, 1345-64.

Gould, E., D. Mustard and B. Weinberg (2002), "Crime Rates and Local Labor Market Opportunities in the United States: 1979-1997," Review of Economics and Statistics 84, 45-61.

Grogger, J. (1998), "Market Wages and Youth Crime," Journal of Labor Economics $16,756-791$.

Hjalmarsson, R. (2008), "Criminal Justice Involvement and High School Completion," Journal of Urban Economics 63, 613-630.

Jacob, B. and L. Lefgren (2003), "Are Idle Hands the Devil's Workshop? Incapacitation, Concentration and Juvenile Crime," American Economic Review 93, 1560-1577.

Levitt, S. and L. Lochner (2001), "The Determinants of Juvenile Crime," in Gruber, J. (ed.), Risky Behavior among Youths: An Economic Analysis, Chicago: University of Chicago Press.

Lochner, L. (2004), "Education, Work and Crime: A Human Capital Approach," International Economic Review 45, 811-843.

Lochner, L. (2011), "Non-Production Benefits of Education: Crime, Health and Good Citizenship," in Hanushek, E., S. Machin and L. Woessmann (eds.), Handbook of the Economics of Education, Volume 4, North Holland: Amsterdam.

Lochner, L. and E. Moretti (2004), "The Effect of Education on Crime: Evidence from Prison Inmates, Arrests and Self-Reports," American Economic Review 94, 155-189.

Luallen, J. (2006), "School's Out......Forever: A Study of Juvenile Crime, At-Risk Youths and Teacher Strikes," Journal of Urban Economics 59, 75-103.

Machin, S., O. Marie and S. Vujić (2011), "The Crime Reducing Effect of Education," Economic Journal 121, 463-84. 
Machin, S. and C. Meghir (2004), "Crime and Economic Incentives," Journal of Human Resources 39, 958-979.

Machin, S. and A. Vignoles (2005) (eds.), "What's the Good of Education? The Economics of Education in the United Kingdom," Princeton University Press: Princeton.

Mocan, N. and B. Unel (2011), "Skill-biased Technological Change, Earnings of Unskilled Workers, and Crime," National Bureau of Economic Research Working Paper 17605.

Oreopoulos, P. (2007), "Do Dropouts Drop out too Soon? Wealth, Health and Happiness from Compulsory Schooling," Journal of Public Economics 91, 2213-2229.

Sabates, R. (2010), "Educational Expansion, Economic Growth and Antisocial Behaviour: Evidence from England," Educational Studies, 36, 165-173.

Sabates, R. and L. Feinstein (2008), "Effects of Government Initiatives on Youth Crime," Oxford Economic Papers 60, 462-83.

Tauchen, H., A. Witte, and H. Griesinger (1994), "Criminal Deterrence: Revisiting the Issue with a Birth Cohort," Review of Economics and Statistics 76, 399-412. 
Figure 1:

\section{Changes in Post Compulsory Education Participation from 1960 to 2002}

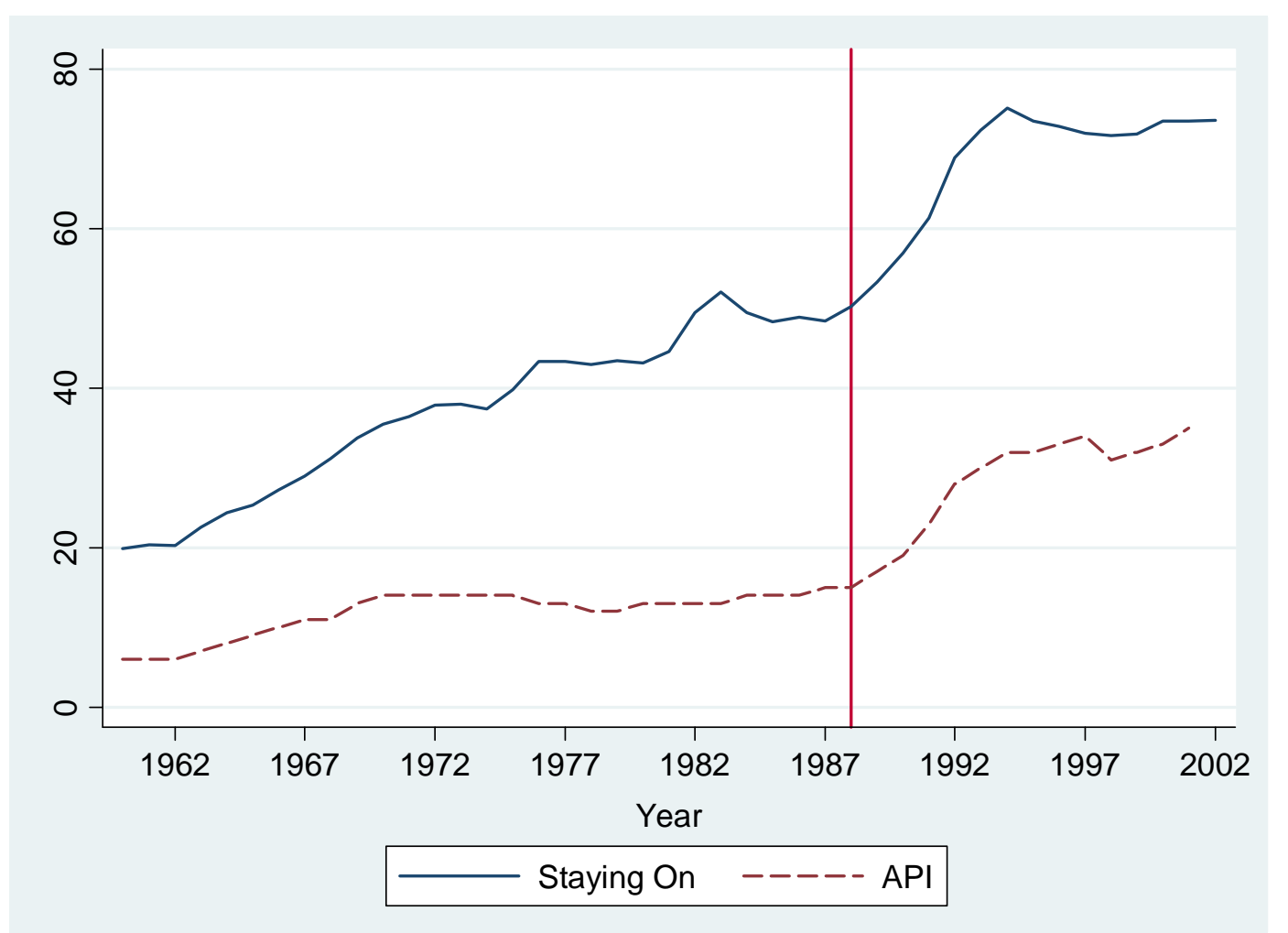

Notes: Staying On measures the percentage of a cohort of individuals in England and Wales who are aged 16 in a certain year and who are enrolled in full time education (data from the Department for Education and Skills (DfES) are kindly provided by Damon Clark). The API is the Age Participation Index and is the percentage of individuals in England and Wales aged under 21 who enter higher education each year (data from DfES - note that there was a change in how this index was calculated from 2002 onwards and the series stops here in 2001 for consistency). The vertical line marks the 1988 introduction of the GCSE examination system. 
Figure 2: EducationMeasures by Cohort

Proportion of 16 to 21 Year Olds Still in Full Time Education

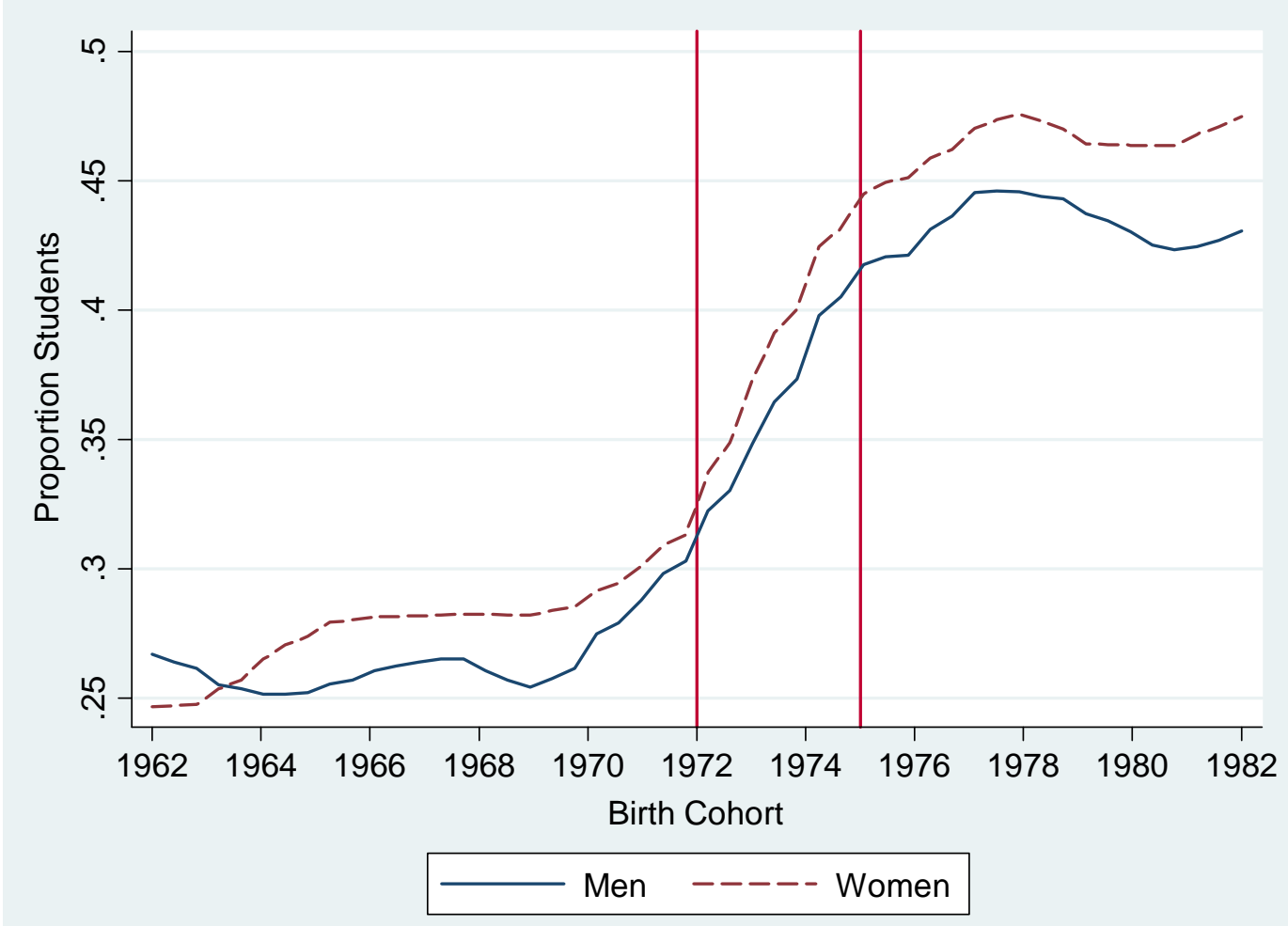

Proportion of 16 to 21 Year Olds Staying on After 16 by Cohort

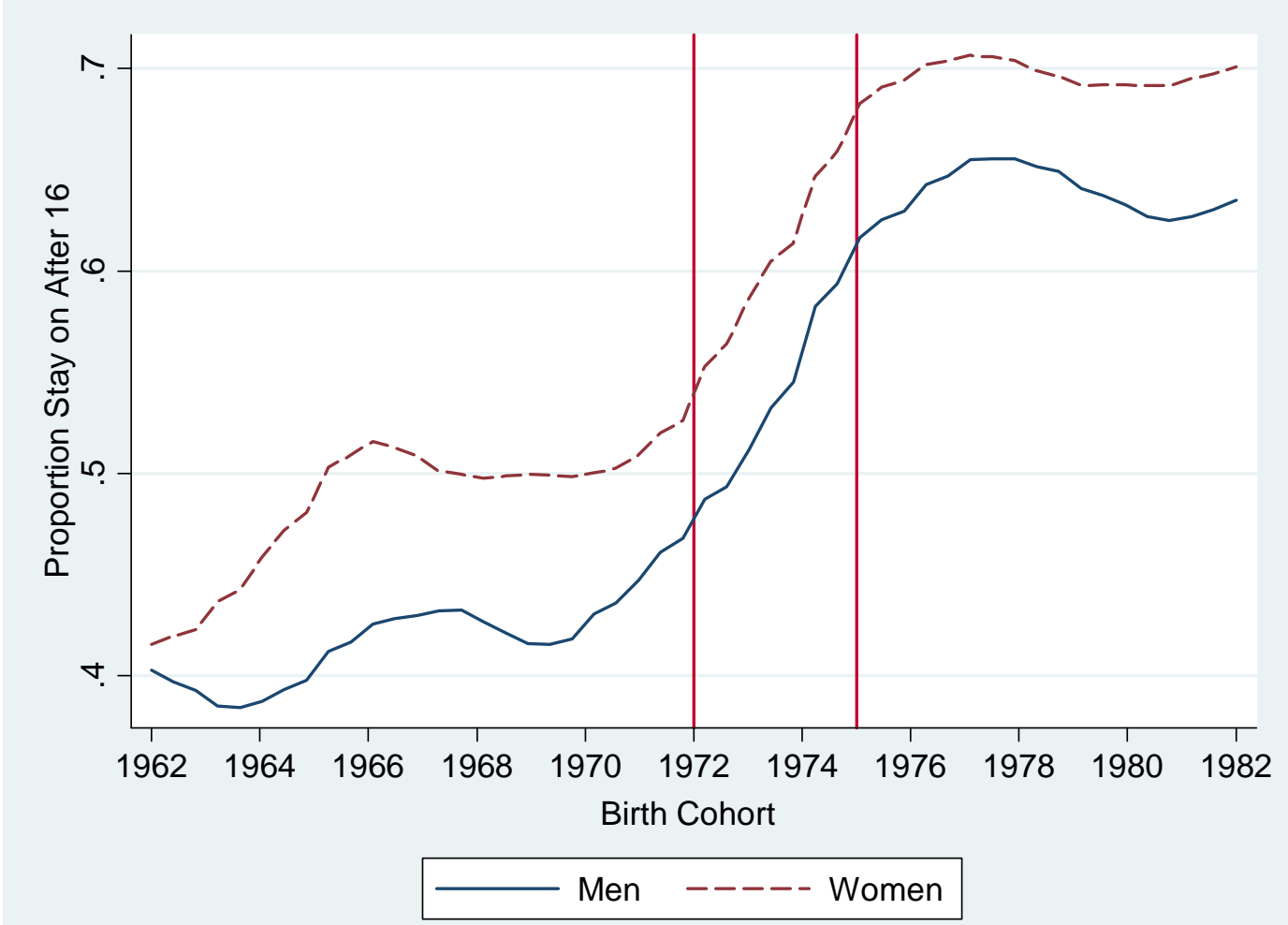

Source: The Labour Force Survey. Authors' calculations. The two vertical lines (i.e., 1972 to 1975 inclusive) denote the education expansion cohorts. 


\section{Figure 3:}

Conviction Rates for Individuals Aged 16 to 21 by Cohort and Gender

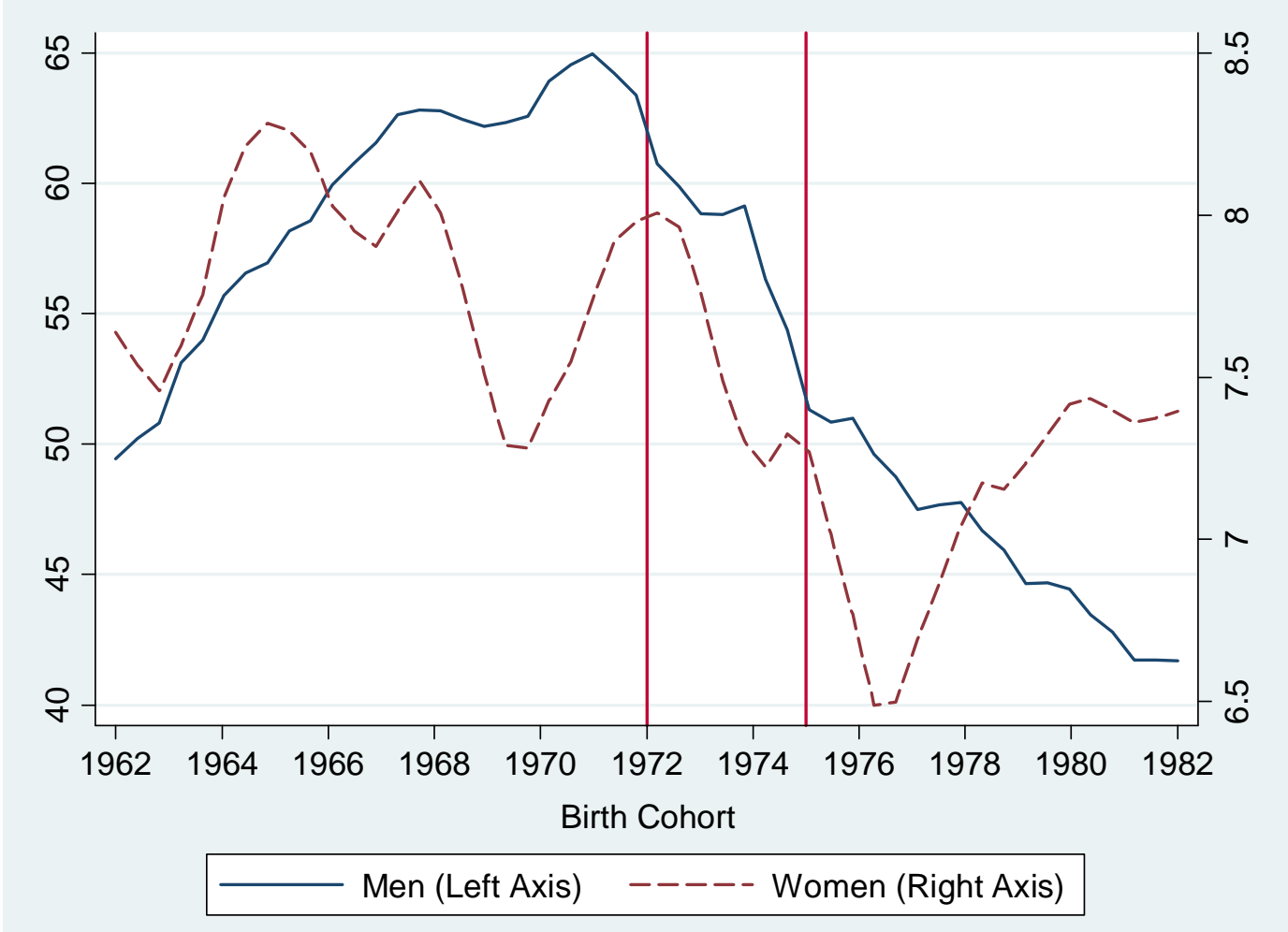

Source: The Offenders Index Database. Authors' calculations. The two vertical lines (i.e., 1972 to 1975 inclusive) denote the education expansion cohorts. 
Figure 4:

\section{Property and Violent Conviction Rates for Men Aged 16 to 21 by Cohort}

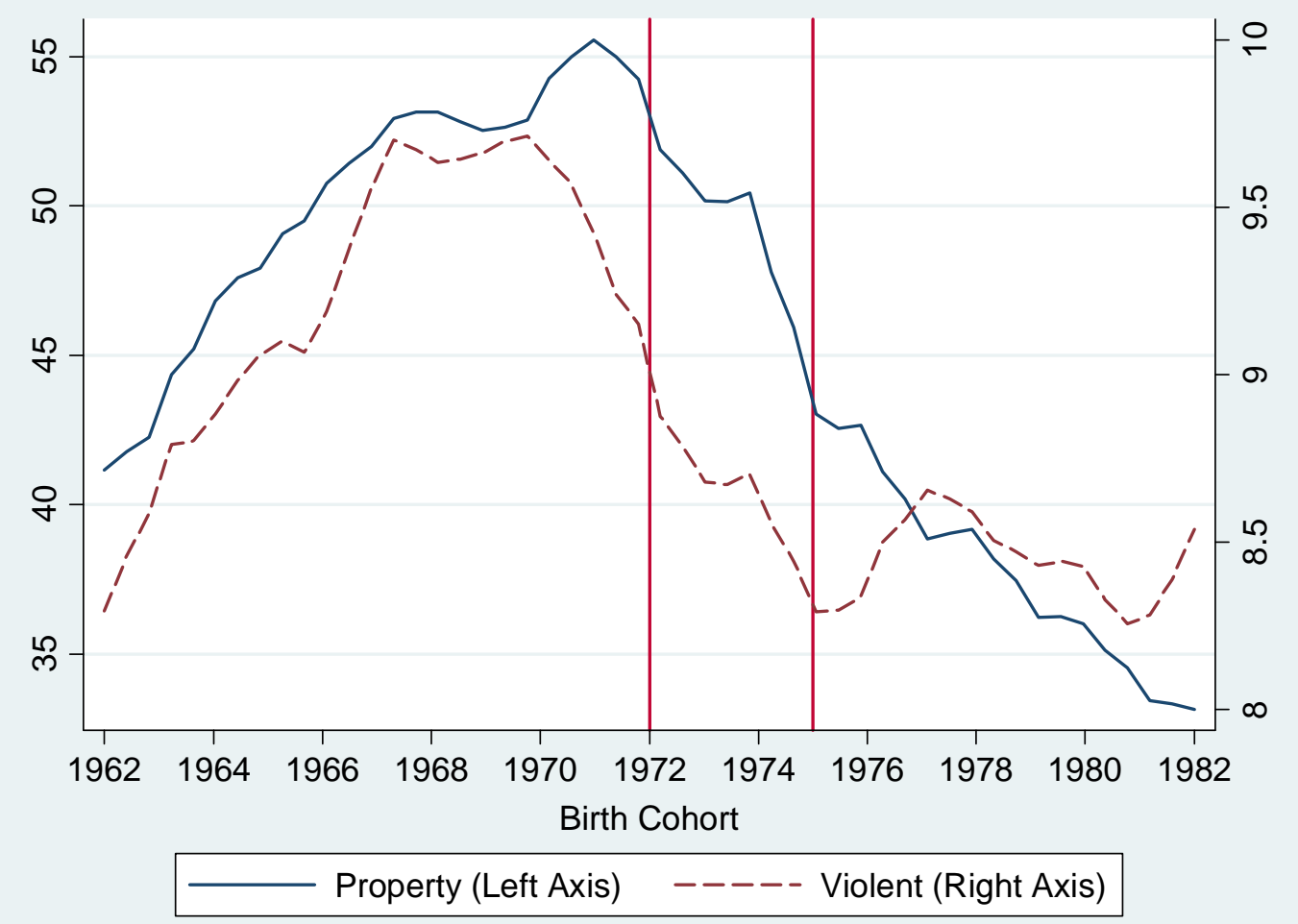

Source: The Offenders Index Database. Authors' calculations. The two vertical lines (i.e., 1972 to 1975 inclusive) denote the education expansion cohorts. 
Table 1: Education and Crime Reduced Forms - Men and Women

\begin{tabular}{|c|c|c|c|c|c|c|}
\hline & \multicolumn{3}{|c|}{ Men, Aged 16-21, Born 1962-1982 } & \multicolumn{3}{|c|}{ Women, Aged 16-21, Born 1962-82 } \\
\hline & \multicolumn{2}{|c|}{$\begin{array}{c}\text { Education } \\
\text { Reduced Forms }\end{array}$} & \multirow{2}{*}{$\begin{array}{c}\begin{array}{c}\text { Crime } \\
\text { Reduced Form }\end{array} \\
\text { Log(Total } \\
\begin{array}{c}\text { Conviction } \\
\text { Rate) }\end{array}\end{array}$} & \multicolumn{2}{|c|}{$\begin{array}{c}\text { Education } \\
\text { Reduced Forms }\end{array}$} & \multirow{2}{*}{$\begin{array}{c}\text { Crime } \\
\text { Reduced Form } \\
\text { Log(Total } \\
\begin{array}{c}\text { Conviction } \\
\text { Rate) }\end{array}\end{array}$} \\
\hline & $\begin{array}{l}\text { Proportion } \\
\text { Students }\end{array}$ & $\begin{array}{c}\text { Proportion } \\
\text { Staying on } \\
\text { After } 16 \\
\end{array}$ & & $\begin{array}{c}\text { Proportion } \\
\text { Students }\end{array}$ & $\begin{array}{c}\text { Proportion } \\
\text { Staying on } \\
\text { After } 16 \\
\end{array}$ & \\
\hline Cohort 1972 & $\begin{array}{c}0.031 \\
(0.019)\end{array}$ & $\begin{array}{c}0.028 \\
(0.0242)\end{array}$ & $\begin{array}{c}-0.050^{*} \\
(0.030)\end{array}$ & $\begin{array}{l}0.020^{*} \\
(0.012)\end{array}$ & $\begin{array}{c}0.012 \\
(0.015)\end{array}$ & $\begin{array}{l}-0.015 \\
(0.063)\end{array}$ \\
\hline Cohort 1973 & $\begin{array}{c}0.067 * * * \\
(0.016)\end{array}$ & $\begin{array}{c}0.055^{* * *} \\
(0.019)\end{array}$ & $\begin{array}{c}-0.122 * * * \\
(0.041)\end{array}$ & $\begin{array}{c}0.071 * * * \\
(0.012)\end{array}$ & $\begin{array}{c}0.061 * * * \\
(0.017)\end{array}$ & $\begin{array}{l}-0.082 \\
(0.063)\end{array}$ \\
\hline Cohort 1974 & $\begin{array}{c}0.106 * * * \\
(0.020)\end{array}$ & $\begin{array}{c}0.112 * * * \\
(0.024)\end{array}$ & $\begin{array}{c}-0.080^{*} \\
(0.046)\end{array}$ & $\begin{array}{c}0.106^{* * *} \\
(0.016)\end{array}$ & $\begin{array}{c}0.098 * * * \\
(0.023)\end{array}$ & $\begin{array}{c}-0.222 * * * \\
(0.073)\end{array}$ \\
\hline Cohort 1975 & $\begin{array}{c}0.137 * * * \\
(0.025)\end{array}$ & $\begin{array}{c}0.163 * * * \\
(0.031)\end{array}$ & $\begin{array}{c}-0.239 * * * \\
(0.039)\end{array}$ & $\begin{array}{c}0.133 * * * \\
(0.019)\end{array}$ & $\begin{array}{c}0.153 * * * \\
(0.022)\end{array}$ & $\begin{array}{l}-0.112^{*} \\
(0.059)\end{array}$ \\
\hline Post-EE Cohort & $\begin{array}{c}0.145^{* * * *} \\
(0.028)\end{array}$ & $\begin{array}{c}0.184 * * * \\
(0.031)\end{array}$ & $\begin{array}{c}-0.248 * * * \\
(0.039)\end{array}$ & $\begin{array}{c}0.139 * * * \\
(0.023)\end{array}$ & $\begin{array}{c}0.171 * * * \\
(0.025)\end{array}$ & $\begin{array}{c}-0.238 * * \\
(0.087)\end{array}$ \\
\hline $\begin{array}{l}\text { F-Test of Joint } \\
\text { Significance of Cohort } \\
\text { 1972, 1973, 1974, } 1975\end{array}$ & $\begin{array}{c}15.32 \\
{[p=0.00]}\end{array}$ & $\begin{array}{c}9.64 \\
{[p=0.00]}\end{array}$ & $\begin{array}{c}10.59 \\
{[p=0.00]}\end{array}$ & $\begin{array}{c}18.27 \\
{[p=0.00]}\end{array}$ & $\begin{array}{c}16.05 \\
{[p=0.00]}\end{array}$ & $\begin{array}{c}2.41 \\
{[p=0.05]}\end{array}$ \\
\hline Cubic in Age & Yes & Yes & Yes & Yes & Yes & Yes \\
\hline Quadratic in Cohort & Yes & Yes & Yes & Yes & Yes & Yes \\
\hline Demographic Controls & Yes & Yes & Yes & Yes & Yes & Yes \\
\hline Sample Size & 125 & 125 & 125 & 125 & 125 & 125 \\
\hline
\end{tabular}

Notes: Standard errors in round parentheses. * ${ }^{* *}$ and $* * *$ respectively denote significance at the 10,5 or 1 percent level. The demographic controls included in all specifications for each cohort-age cell are: proportion non-white, proportion living in London, and proportion living in Wales. 
Table 2: OLS and 2SLS Results - Men and Women - Total Convictions

\begin{tabular}{|c|c|c|c|}
\hline & & \multicolumn{2}{|c|}{ Aged 16-21, Born 1962-82 } \\
\hline & & $\begin{array}{c}\text { Men - } \\
\text { Log(Total } \\
\text { Conviction Rate) }\end{array}$ & $\begin{array}{c}\text { Women - } \\
\text { Log(Total } \\
\text { Conviction Rate) }\end{array}$ \\
\hline \multirow{2}{*}{$\begin{array}{l}\text { Proportion } \\
\text { Students }\end{array}$} & OLS & $\begin{array}{c}-0.427 * * * \\
(0.162)\end{array}$ & $\begin{array}{l}-0.220 \\
(0.299)\end{array}$ \\
\hline & 2SLS & $\begin{array}{c}-1.886 * * * \\
(0.503)\end{array}$ & $\begin{array}{c}-1.302 * * \\
(0.541)\end{array}$ \\
\hline \multirow{2}{*}{$\begin{array}{l}\text { Proportion Staying } \\
\text { on After } 16\end{array}$} & OLS & $\begin{array}{c}-0.390 * * * \\
(0.126)\end{array}$ & $\begin{array}{l}-0.183 \\
(0.247)\end{array}$ \\
\hline & 2SLS & $\begin{array}{c}-1.743 * * * \\
(0.498)\end{array}$ & $\begin{array}{c}-1.099 * * \\
(0.473)\end{array}$ \\
\hline Cubic in Age & & Yes & Yes \\
\hline Quadratic in Cohort & & Yes & Yes \\
\hline Demographic Controls & & Yes & Yes \\
\hline Sample Size & & 125 & 125 \\
\hline
\end{tabular}

Notes: Standard errors in round parentheses. ${ }^{* * *}$ and $* * *$ respectively denote significance at the 10,5 or 1 percent level.The demographic controls included in all specifications for each cohort-age cell are: proportion non-white, proportion living in London, and proportion living inWales. 
Table 3: Crime Reduced Forms, OLS and IV Results - Men - Property and Violent Convictions

\begin{tabular}{|c|c|c|c|c|c|c|}
\hline & \multicolumn{2}{|c|}{ Crime Reduced Forms } & \multicolumn{4}{|c|}{ OLS and 2SLS Estimates } \\
\hline & $\begin{array}{c}\log (\text { Property } \\
\text { Conviction Rate })\end{array}$ & $\begin{array}{c}\log (\text { Violent } \\
\text { Conviction Rate })\end{array}$ & & & $\begin{array}{c}\text { Log(Property } \\
\text { Conviction Rate) }\end{array}$ & $\begin{array}{c}\log (\text { Violent } \\
\text { Conviction Rate) }\end{array}$ \\
\hline Cohort 1972 & $\begin{array}{l}-0.043 \\
(0.036)\end{array}$ & $\begin{array}{l}-0.064 * \\
(0.035)\end{array}$ & & OLS & $\begin{array}{c}-0.439 * * \\
(0.191)\end{array}$ & $\begin{array}{l}-0.371 \\
(0.245)\end{array}$ \\
\hline Cohort 1973 & $\begin{array}{c}-0.117 * * \\
(0.049)\end{array}$ & $\begin{array}{c}-0.121 * * * \\
(0.046)\end{array}$ & $\begin{array}{l}\text { Proportion } \\
\text { Students }\end{array}$ & & & \\
\hline Cohort 1974 & $\begin{array}{l}-0.069 \\
(0.054)\end{array}$ & $\begin{array}{c}-0.107 * * \\
(0.051)\end{array}$ & & 2SLS & $\begin{array}{c}-1.931 * * * \\
(0.540)\end{array}$ & $\begin{array}{c}-1.417 * * * \\
(0.504)\end{array}$ \\
\hline Cohort 1975 & $\begin{array}{c}-0.241^{* * * *} \\
(0.045)\end{array}$ & $\begin{array}{c}-0.193 * * * \\
(0.064)\end{array}$ & & OLS & $\begin{array}{c}-0.382 * * * \\
(0.147)\end{array}$ & $\begin{array}{c}-0.442 * * \\
(0.208)\end{array}$ \\
\hline Post EE Cohort & $\begin{array}{c}-0.260 * * * \\
(0.055)\end{array}$ & $\begin{array}{c}-0.135^{* *} \\
(0.082)\end{array}$ & $\begin{array}{l}\text { Proportion } \\
\text { Staying on } \\
\text { After } 16\end{array}$ & & & \\
\hline $\begin{array}{l}\text { F-Test of Joint } \\
\text { Significance of Cohort } \\
\text { 1972, 1973, 1974, } 1975\end{array}$ & $\begin{array}{c}9.51 \\
{[p=0.00]}\end{array}$ & $\begin{array}{c}2.81 \\
{[p=0.03]}\end{array}$ & & 2SLS & $\begin{array}{c}-1.797 * * * \\
(0.542)\end{array}$ & $\begin{array}{c}-1.259 * * \\
(0.503)\end{array}$ \\
\hline Cubic in Age & Yes & Yes & & & Yes & Yes \\
\hline Quadratic in Cohort & Yes & Yes & & & Yes & Yes \\
\hline Demographic Controls & Yes & Yes & & & Yes & Yes \\
\hline Sample Size & 125 & 125 & & & 125 & 125 \\
\hline
\end{tabular}

Notes: Standard errors in round parentheses. ${ }^{*} * *$ and $* * *$ respectively denote significance at the 10,5 or 1 percent level. The demographic controls included in all specifications for each cohort-age cell are: proportion non-white, proportion living in London, and proportion living in Wales. 
Table 4: Qualification Attainment and Wages - Men, Aged 25-30

Men, Aged 25-30, Born 1962-1982 - LFS 1993 to 2010

\begin{tabular}{|c|c|c|c|c|c|}
\hline Panel A: Reduced Forms & $\begin{array}{c}\text { Staying On } \\
\text { After } 16\end{array}$ & $\begin{array}{l}\text { Age Left } \\
\text { School }\end{array}$ & $\begin{array}{c}\text { Low } \\
\text { Qualification }\end{array}$ & $\begin{array}{c}\text { Log(Weekly } \\
\text { Wages) }\end{array}$ & $\begin{array}{l}\text { Log(Hourly } \\
\text { Wages })\end{array}$ \\
\hline Cohort 1972 & $\begin{array}{c}0.025 * * * \\
(0.007)\end{array}$ & $\begin{array}{c}0.232 * * * \\
(0.046)\end{array}$ & $\begin{array}{c}-0.026^{* * * *} \\
(0.006)\end{array}$ & $\begin{array}{l}0.025 * \\
(0.013)\end{array}$ & $\begin{array}{c}0.027 * * \\
(0.013)\end{array}$ \\
\hline Cohort 1973 & $\begin{array}{c}0.043 * * * \\
(0.009)\end{array}$ & $\begin{array}{c}0.350 * * * \\
(0.056)\end{array}$ & $\begin{array}{c}-0.047 * * * \\
(0.009)\end{array}$ & $\begin{array}{c}0.050 * * * \\
(0.012)\end{array}$ & $\begin{array}{c}0.061 * * * \\
(0.014)\end{array}$ \\
\hline Cohort 1974 & $\begin{array}{c}0.104 * * * \\
(0.009)\end{array}$ & $\begin{array}{c}0.597 * * * \\
(0.063)\end{array}$ & $\begin{array}{c}-0.068 * * * \\
(0.009)\end{array}$ & $\begin{array}{c}0.057 * * * \\
(0.011)\end{array}$ & $\begin{array}{c}0.084 * * * \\
(0.014)\end{array}$ \\
\hline Cohort 1975 & $\begin{array}{c}0.141 * * * \\
(0.009)\end{array}$ & $\begin{array}{c}0.713 * * * \\
(0.063)\end{array}$ & $\begin{array}{c}-0.071 * * * \\
(0.011)\end{array}$ & $\begin{array}{c}0.084 * * * \\
(0.014)\end{array}$ & $\begin{array}{c}0.111 * * * \\
(0.016)\end{array}$ \\
\hline Post EE Cohort & $\begin{array}{c}0.167 * * * \\
(0.013)\end{array}$ & $\begin{array}{c}0.693 * * * \\
(0.081)\end{array}$ & $\begin{array}{c}-0.062 * * * \\
(0.010)\end{array}$ & $\begin{array}{c}0.084 * * * \\
(0.015)\end{array}$ & $\begin{array}{c}0118 * * * \\
(0.018)\end{array}$ \\
\hline $\begin{array}{l}\text { F-Test of Joint Significance of } \\
\text { Cohort 1972, 1973, 1974, } 1975\end{array}$ & $\begin{array}{c}95.23 \\
{[p=0.00]}\end{array}$ & $\begin{array}{c}43.08 \\
{[p=0.00]}\end{array}$ & $\begin{array}{c}17.76 \\
{[p=0.00]}\end{array}$ & $\begin{array}{c}11.57 \\
{[p=0.00]}\end{array}$ & $\begin{array}{c}14.88 \\
{[p=0.00]}\end{array}$ \\
\hline Sample Size & 271,192 & 271,192 & 265,299 & 50,753 & 49,369 \\
\hline \multicolumn{6}{|l|}{ Panel B: OLS and 2SLS } \\
\hline Staying On After 16 & \multicolumn{2}{|c|}{ OLS } & $\begin{array}{c}-0.359 * * * \\
(0.004) \\
-0.521 * * * \\
(0.055)\end{array}$ & $\begin{array}{c}0.208 * * * \\
(0.007) \\
0.479 * * * \\
(0.095)\end{array}$ & $\begin{array}{c}0.273 * * * \\
(0.007) \\
0.670 * * * \\
(0.104)\end{array}$ \\
\hline Age Left School & \multicolumn{2}{|c|}{ OLS } & $\begin{array}{c}-0.104 * * * \\
(0.001) \\
-0.102 * * * \\
(0.008)\end{array}$ & $\begin{array}{c}0.042 * * * \\
(0.001) \\
0.099 * * * \\
(0.016)\end{array}$ & $\begin{array}{c}0.054 * * * \\
(0.001) \\
0.131 * * * \\
(0.018)\end{array}$ \\
\hline
\end{tabular}

Notes: Standard errors clustered by age and cohort in round parentheses. ${ }^{*}, * *$ and $* * *$ respectively denote significance at the 10,5 or 1 percent level. All specifications include a cubic in age and a quadratic in cohort. They also include dummies for being non-white, living in London, and living in Wales. 


\section{Data Appendix}

\section{A.1 The Offenders Index Database (OID)}

Our analysis uses Offenders Index Database (OID) data from 1978 to 2002, which we match to Labour Force Survey (LFS) data for England and Wales by age cohort and survey year. The version of the OID to which we have access holds criminal history data for offenders convicted of standard list offences between 1963 and 2002. Standard list offences are all indictable or triable either way offences, plus a few of the more serious summary offences. Standard list class codes are set out in the Offenders Index (OI) codebook. The data are derived from the Court Appearances system and are updated quarterly.

The data set holds anonymous samples (of 4 weeks) for each year. The selection of offenders is from analysis of the court appearance data using the date to select relevant offenders. Selection of offenders occurs where they appeared in court during the first week in March, the second week in June, the third week in September and the third week in November. ${ }^{14}$

Matching OID to ONS population data, we calculated offending rates (per 10,000 population) by age cohort and year, separately for men and women, using date of birth and gender variables. Criminal offences have been broadly categorised as property crimes (burglary and theft and handling stolen goods) and violent crimes (violence against the person and robbery), using categorisation in the Offence Class Code of variables. ${ }^{15}$ The total conviction rate we use is the sum of the two. We focus on youth convictions for individuals aged 16 to 21 years old enabling us to have a reasonably well balanced panel

\footnotetext{
${ }^{14}$ The first week in any calendar month is the week where the Monday is the first Monday in that month.

${ }^{15} \mathrm{We}$ do not consider sexual offences since there are very few of them and their relationship with education is contrary to that of most other crimes (as in the case of rape in Lochner and Moretti, 2004).
} 
around the policy years (from the 1988 introduction of the GCSE onwards) since the cohorts studied were born between 1962 and 1982.

The data structure for men and women, with means of the total conviction rate per 10,000 population, as well as property and violent conviction rates, are presented in Table A1.

Table A1: Offenders Index Database (OID) - Descriptives

\begin{tabular}{cccccccc}
\hline $\begin{array}{c}\text { OID } \\
\text { Year }\end{array}$ & $\begin{array}{c}\text { Age } \\
\text { Range }\end{array}$ & $\begin{array}{c}\text { Men, Total } \\
\text { Convictions }\end{array}$ & $\begin{array}{c}\text { Men, } \\
\text { Property }\end{array}$ & $\begin{array}{c}\text { Men, } \\
\text { Violent }\end{array}$ & $\begin{array}{c}\text { Women, Total } \\
\text { Convictions }\end{array}$ & $\begin{array}{c}\text { Women, } \\
\text { Property }\end{array}$ & $\begin{array}{c}\text { Women, } \\
\text { Violent }\end{array}$ \\
\hline 1978 & $16-16$ & 44.11 & 39.60 & 4.51 & 5.09 & 4.32 & 0.77 \\
1979 & $16-17$ & 45.22 & 38.27 & 6.95 & 7.03 & 6.24 & 0.79 \\
1980 & $16-18$ & 50.44 & 41.49 & 8.95 & 8.50 & 7.70 & 0.80 \\
1981 & $16-19$ & 54.31 & 45.46 & 8.85 & 7.28 & 6.66 & 0.62 \\
1982 & $16-20$ & 63.71 & 54.06 & 9.65 & 8.80 & 8.14 & 0.65 \\
1983 & $16-21$ & 57.97 & 49.01 & 8.96 & 8.03 & 7.17 & 0.87 \\
1984 & $16-21$ & 61.56 & 52.78 & 8.79 & 8.52 & 7.79 & 0.73 \\
1985 & $16-21$ & 60.74 & 51.53 & 9.21 & 8.58 & 7.93 & 0.65 \\
1986 & $16-21$ & 53.39 & 44.71 & 8.68 & 7.27 & 6.56 & 0.71 \\
1987 & $16-21$ & 69.41 & 59.97 & 9.43 & 7.43 & 6.70 & 0.72 \\
1988 & $16-21$ & 65.11 & 55.23 & 9.88 & 7.25 & 6.29 & 0.96 \\
1989 & $16-21$ & 57.74 & 47.54 & 10.20 & 7.55 & 6.48 & 1.07 \\
1990 & $16-21$ & 60.03 & 50.52 & 9.51 & 7.81 & 6.93 & 0.88 \\
1991 & $16-21$ & 61.58 & 53.23 & 8.35 & 8.14 & 7.31 & 0.83 \\
1992 & $16-21$ & 59.99 & 51.13 & 8.87 & 7.68 & 6.70 & 0.99 \\
1993 & $16-21$ & 53.12 & 43.49 & 9.62 & 6.69 & 5.90 & 0.79 \\
1994 & $16-21$ & 50.84 & 41.34 & 9.50 & 6.83 & 5.94 & 0.88 \\
1995 & $16-21$ & 48.87 & 41.14 & 7.73 & 6.40 & 5.79 & 0.62 \\
1996 & $16-21$ & 45.53 & 37.71 & 7.81 & 6.06 & 5.51 & 0.55 \\
1997 & $16-21$ & 46.24 & 37.17 & 9.06 & 6.94 & 6.06 & 0.88 \\
1998 & $16-21$ & 43.76 & 35.68 & 8.08 & 6.76 & 6.11 & 0.65 \\
1999 & $17-21$ & 44.11 & 35.66 & 8.45 & 7.85 & 7.13 & 0.72 \\
2000 & $18-21$ & 43.32 & 35.04 & 8.28 & 9.15 & 8.35 & 0.80 \\
2001 & $19-21$ & 41.82 & 33.44 & 8.38 & 8.51 & 7.84 & 0.67 \\
2002 & $20-21$ & 38.73 & 30.72 & 8.01 & 7.31 & 6.76 & 0.55 \\
\hline
\end{tabular}

Note: There was an unexplained jump in the number of convictions recorded in 1999 in the OID, so that year is interpolated using cohorts between 1998 and 2000. Dropping this year from our sample yielded similar results to the ones reported in the main body of the paper.

\section{A.2 The Labour Force Survey (LFS)}

The LFS began in 1975 and was initially a biannual survey (up to 1983), after which it became annual (up to 1991) and has since become a quarterly (since 1991) 
sample survey of households living at private addresses in the United Kingdom. Its purpose is to provide information on the UK labour market that can then be used to develop, manage, evaluate and report on labour market policies. It is conducted by the Office for National Statistics (ONS).

For the purposes of this paper, we make use of two distinct sets of LFS data, restricted to individuals in England and Wales:

i) Cohort level averages (weighted by individual weights) from 1978 to 2002, matched to OID data in order to analyse the impact of education expansion on youth crime. ${ }^{16}$

ii) Individual data from 1993 to 2010 to investigate the effect of the policy on later life outcomes for the same cohorts.

The first set of LFS data is mainly used to obtain averages of educational attainment levels by cohort in order to estimate actual impact of the expansion policy. The two measures of education for our individuals aged 16 to 21 and born between 1962 and 1982 were defined as:

- 'Student': Individual was still enrolled at school at the time of survey.

- 'Staying On': Individual is still enrolled in school and is older than 16 or has left full time education after that age.

Table A2.1 below describes the education measures by year, age range, and gender.

Table A2.1: LFS 1978-2002 - Descriptives

\begin{tabular}{lccccc}
\hline $\begin{array}{l}\text { LFS } \\
\text { Year }\end{array}$ & $\begin{array}{c}\text { Age } \\
\text { Range }\end{array}$ & $\begin{array}{c}\text { Men, } \\
\text { Proportion } \\
\text { Students }\end{array}$ & $\begin{array}{c}\text { Men, } \\
\text { Proportion } \\
\text { Staying On }\end{array}$ & $\begin{array}{c}\text { Women, } \\
\text { Proportion } \\
\text { Students }\end{array}$ & $\begin{array}{c}\text { Women, } \\
\text { Proportion } \\
\text { Staying On }\end{array}$ \\
\hline 1978 & $16-16$ & 0.713 & 0.713 & 0.672 & 0.672 \\
1979 & $16-17$ & 0.521 & 0.562 & 0.473 & 0.511 \\
1980 & $16-18$ & 0.413 & 0.471 & 0.417 & 0.481 \\
1981 & $16-19$ & 0.327 & 0.395 & 0.360 & 0.452 \\
1982 & $16-20$ & 0.293 & 0.399 & 0.320 & 0.466
\end{tabular}

${ }^{16}$ In the early years when the LFS was biannual, we interpolate data for missing years. 


\begin{tabular}{|c|c|c|c|c|c|}
\hline 1983 & $16-21$ & 0.264 & 0.407 & 0.289 & 0.484 \\
\hline 1984 & $16-21$ & 0.267 & 0.412 & 0.279 & 0.494 \\
\hline 1985 & $16-21$ & 0.250 & 0.407 & 0.276 & 0.486 \\
\hline 1986 & $16-21$ & 0.250 & 0.411 & 0.270 & 0.492 \\
\hline 1987 & $16-21$ & 0.271 & 0.431 & 0.276 & 0.498 \\
\hline 1988 & $16-21$ & 0.267 & 0.426 & 0.284 & 0.505 \\
\hline 1989 & $16-21$ & 0.270 & 0.429 & 0.290 & 0.505 \\
\hline 1990 & $16-21$ & 0.291 & 0.452 & 0.325 & 0.525 \\
\hline 1991 & $16-21$ & 0.322 & 0.479 & 0.344 & 0.558 \\
\hline 1992 & $16-21$ & 0.371 & 0.542 & 0.395 & 0.611 \\
\hline 1993 & $16-21$ & 0.404 & 0.581 & 0.434 & 0.649 \\
\hline 1994 & $16-21$ & 0.438 & 0.616 & 0.450 & 0.676 \\
\hline 1995 & $16-21$ & 0.438 & 0.641 & 0.464 & 0.695 \\
\hline 1996 & $16-21$ & 0.434 & 0.636 & 0.458 & 0.692 \\
\hline 1997 & $16-21$ & 0.423 & 0.639 & 0.459 & 0.697 \\
\hline 1998 & $16-21$ & 0.431 & 0.636 & 0.471 & 0.702 \\
\hline 1999 & $17-21$ & 0.367 & 0.612 & 0.396 & 0.677 \\
\hline 2000 & $18-21$ & 0.316 & 0.605 & 0.344 & 0.668 \\
\hline 2001 & $19-21$ & 0.275 & 0.597 & 0.284 & 0.648 \\
\hline 2002 & $20-21$ & 0.253 & 0.588 & 0.263 & 0.633 \\
\hline
\end{tabular}

Note: In the early years of the LFS, the survey was biannual (in 1977, 1979, 1981 and 1983), after which it became annual. For the early missing years (1978, 1980, and 1982), we impute values by cohort by generating averages between the previous and next year.

The second use of the LFS comes from our interest in the effect of the education expansion on productivity related outcomes later in the lives of the cohorts that experienced this education expansion. Wage information was first reported in the first quarter of 1993 and the data is available up to the last quarter of 2010. Since all the information necessary for this part of the analysis (education and outcomes) is available within the LFS, we can use individual micro information here rather than using cohort level averages. The variables we look at are:

- 'Staying On': $\quad$ Individual left school after the compulsory age of 16

- 'Edage': $\quad$ Age individual left full time education

- 'LowQual': $\quad$ Left school without obtaining an intermediate qualification

- 'Wkearn': Gross weekly earnings

- 'Hrearn': Gross hourly earnings (i.e. weekly earnings / hours worked) 
The sample of individuals is restricted to males born between 1962 and 1982, aged 25 to 30 , but observed in later LFS years, which corresponds to the same cohorts used in the analysis of education expansion on youth crime. Table A2.2 reports averages for these variables by year and age range.

Table A2.2: LFS 1993-2010, Men - Descriptives

\begin{tabular}{lcccccc}
\hline $\begin{array}{l}\text { LFS } \\
\text { Year }\end{array}$ & $\begin{array}{c}\text { Age } \\
\text { Range }\end{array}$ & $\begin{array}{c}\text { Staying On } \\
\text { After 16 }\end{array}$ & $\begin{array}{c}\text { Age Left } \\
\text { School }\end{array}$ & $\begin{array}{c}\text { Low } \\
\text { Qual }\end{array}$ & $\begin{array}{c}\text { Weekly } \\
\text { Wages }\end{array}$ & $\begin{array}{c}\text { Hourly } \\
\text { Wages }\end{array}$ \\
\hline 1993 & $25-30$ & 0.40 & 17.41 & 0.77 & 307.73 & 7.40 \\
1994 & $25-30$ & 0.42 & 17.46 & 0.78 & 297.27 & 7.05 \\
1995 & $25-30$ & 0.42 & 17.43 & 0.77 & 308.45 & 7.38 \\
1996 & $25-30$ & 0.41 & 17.52 & 0.76 & 319.51 & 7.72 \\
1997 & $25-30$ & 0.41 & 17.58 & 0.70 & 325.81 & 7.69 \\
1998 & $25-30$ & 0.42 & 17.70 & 0.68 & 339.34 & 8.00 \\
1999 & $25-30$ & 0.43 & 17.83 & 0.65 & 355.99 & 8.46 \\
2000 & $25-30$ & 0.45 & 17.89 & 0.65 & 370.75 & 8.83 \\
2001 & $25-30$ & 0.48 & 18.14 & 0.63 & 394.83 & 9.47 \\
2002 & $25-30$ & 0.51 & 18.31 & 0.61 & 405.72 & 9.82 \\
2003 & $25-30$ & 0.53 & 18.47 & 0.58 & 411.34 & 9.99 \\
2004 & $25-30$ & 0.55 & 18.52 & 0.57 & 423.78 & 10.49 \\
2005 & $25-30$ & 0.57 & 18.58 & 0.57 & 430.28 & 10.68 \\
2006 & $25-30$ & 0.58 & 18.66 & 0.55 & 430.48 & 10.64 \\
2007 & $25-30$ & 0.58 & 18.72 & 0.54 & 455.11 & 11.11 \\
2008 & $26-30$ & 0.59 & 18.79 & 0.53 & 496.05 & 12.20 \\
2009 & $27-30$ & 0.58 & 18.85 & 0.52 & 477.57 & 11.92 \\
2010 & $28-30$ & 0.57 & 18.79 & 0.52 & 493.09 & 12.19 \\
\hline
\end{tabular}

